\title{
Effectiveness of the superior hypogastric plexus neurolytic block in the management of pelvic abdominal pain in adult patients diagnosed with cancer: A systematic literature review
}

Efectividad del bloqueo neurolítico del plexo hipogástrico superior en el manejo del dolor abdominopélvico en pacientes adultos con diagnóstico de cáncer. Revisión sistemática de la literatura

Diana P. Pérez-Moreno MD, FIPP1, Ricardo Plancarte-Sánchez MD, FIPP2,

Carolina Hernández-Porras MD, FIPP CIPS ${ }^{3}$, María del Rocío Guillén-Núñez MD. ${ }^{3}$

\begin{abstract}
Introduction: Severe oncological pain occurs in up to $60 \%$ of pelvic abdominal cancer patients, being refractory to medical management in up to $30 \%$ of cases. In 1990, the superior hypogastric plexus neurolytic block (SHPB) was described for the control of pain in these patients. This study aimed to evaluate the effectiveness of this technique for the control of oncological pain. Methodology: Studies that evaluated the effectiveness of the SHPB using the classic or transdiscal approach in adult patients with oncological abdominal-pelvic pain were systematically reviewed. A search was conducted in PubMed, EMBASE and Scopus from January 1, 1990, to August 31, 2019, without a language restriction. The visual analog scale (VAS), morphine milligram equivalents (MME) per day, quality of life and presence of complications were recorded. The quality of the studies was evaluated using the Jadad and Ottawa-Newcastle scales.
\end{abstract}

Key words:

Hypogastric plexus, superior hypogastric plexus neurolytic block, Pelvic cancer pain, nerve block

Staff of Pain Clinic and palliative care, Hospital Universitario Nacional de Colombia. Bogotá City.

Chief of Pain Clinic Department, National Institute of Cancerology. México City.

Staff of Pain Clinic, National Institute of Cancerology. México City.

Fecha de recepción: 29 de marzo de 2020

Fecha de aceptación: 12 de abril de 2020

\section{ORCID}

https://orcid.org/0000-0001-7166-8305

Correspondence:

Diana P. Pérez-Moreno, MD.

México City, México.

d.perezmoreno@gmail.com 
Results: Eight studies met the inclusion criteria: 6 were descriptive longitudinal studies, and 2 were controlled clinical trials, comprising 316 patients $(75 \%$ female and $25 \%$ male; average age 53.2 years); the most frequent diagnoses were gynecological (65\%) cancer. An average VAS reduction of 55\%-60.8\% was obtained as well as a MME reduction of $40 \%-60 \%$. Three studies evaluated the quality of life using the (QLQ-C30), (PSS) and Zubrod scale all with positive results. Complications were reported in $18 \%$ of cases, pain related to the puncture was the most frequent. Conclusions: The SHPB may be an effective for the control of severe oncological abdominal-pelvic pain, decreasing the VAS and MME and improving the quality of life of patients.

\section{RESUMEN}

Introducción: El dolor oncológico severo se presenta hasta en el $60 \%$ de los pacientes con cáncer abdominopélvico, siendo refractario al manejo médico hasta en el 30\% de los casos. En 1990, se describió el bloqueo del plexo hipogástrico superior (BPHS) para el control de dolor en estos pacientes. Nuestro objetivo en este estudio fue evaluar la efectividad de esta técnica. Metodología: Se realizó una revisión sistemática de estudios que evaluaron la efectividad del BPHS técnicas guiadas por fluoroscopio en pacientes adultos con dolor oncológico abdominopélvico. Se realizó una búsqueda en Pubmed, EMBASE y Scopus desde el 1de enero de 1990 hasta el 31 de agosto de 2019, sin restricción de idioma. Se evaluó la escala visual análoga, el consumo de opioides: dosis equivalente de morfina día, calidad de vida, presencia de complicaciones y se evaluó la calidad de los estudios mediante escalas Jadad y OttawaNewcastle. Resultados: Ocho estudios cumplieron los criterios de inclusión, 6 fueron longitudinales descriptivos y 2 ensayos clínicos controlados, con un total de 316 pacientes, $75 \%$ femenino y $25 \%$ masculino; edad promedio 53,2 años; diagnóstico más frecuente: Cáncer ginecológico (65\%). Se logró una reducción de la escala visual análoga (EVA) de 55\%-60,8\% y reducción de la dosis equivalente de miligramos de morfina oral día (DEMO) del 40\%-60\%. Tres estudios evaluaron la calidad de vida con las escalas QLQ-C30, PSS y Zubrod, mostrando mejoría en todas. Se reportaron complicaciones en $18 \%$ de los casos, siendo el dolor en el sitio de punción la más frecuente. Conclusiones: El BPHS puede ser efectivo en el control de dolor oncológico de origen abdominopélvico, disminuyendo escala visual análoga (EVA), dosis equivalente de miligramos de morfina oral día (DEMO) y mejorando la calidad de vida. Sin embargo, se requieren de estudios adicionales para dar una recomendación con alta calidad de evidencia.

\section{Palabras clave:}

Plexo hipogástrico, bloqueo neurolítico del plexo hipogástrico superior, dolor pélvico en cáncer, bloqueo de nervio

\section{Introduction}

P ain is a condition of high incidence in patients diagnosed with cancer; it occurs in up to $90 \%$ of cases with moderate to severe intensity and progressive deterioration from the time of presentation. Its presence and inadequate control have been associated with a lower tolerance to treatment, a higher incidence of depression and a decrease in the scores of quality of life scales[1].
According to the World Health Organization (WHO), pharmacological treatment is not sufficient to reduce oncological pain in up to $30 \%$ of patients; therefore, they would benefit from the "fourth step" interventionist techniques on the analgesic pain treatment ladder[2].

However, it has been shown that this strategy should be used early to significantly improve the quality of life by reducing unnecessary suffering and morbidity associated with the disease and treatment 
received[3]. In patients with pancreatic and cervix cancer, early sympathetic neurolytic blocks (celiac ganglion and superior hypogastric plexus (SHP), respectively) have shown positive results in the indexes of the quality of life related to optimal pain control, thus reducing the dose of opioid analgesics and, consequently, adverse effects associated with their chronic use[4]. This finding contributes to improving patients' performance of basic daily activities, reducing the incidence of depression and a greater adherence to palliative care measures[5].

Patients with pelvic-abdominal neoplasms (rectum, bladder, cervix, uterus and prostate) are also affected by severe chronic pain in up to $60 \%$ of cases[6]. This pain is of a mixed nature, secondary to the visceral involvement and distortion and inflammation of the capsules of solid organs (visceral pain), to the alteration of muscular, fascial and joint pelvic structures (somatic pain), and to the infiltration of perineal nerve structures resulting in lumbosacral plexopathies with sensory loss, deafferentation and occasionally complex regional pain syndrome (neuropathic pain)[7]. Although multimodal pharmacological management continues to be the cornerstone of pain treatment, a sympathetic neurolytic block is an efficient therapeutic option. Since the afferent fibers that innervate the pelvic-abdominal organs travel in nerves, trunks and sympathetic ganglia, the intervention of the sympathetic nervous system at the level of the SHP is feasible for the treatment of chronic pain of various etiologies[4],[8].

The SHP is in the retroperitoneal space, extending bilaterally from the lower third of the vertebral body $\mathrm{L} 5$ to the upper third of the vertebral body $\mathrm{S} 1$. Plancarte et al.[8], were the first to describe the superior hypogastric plexus neurolytic block (SHPB) with a posterior approach, using two needles under fluoroscopic guidance with a high success rate.

Alternative methods have been described, such as the posterior transdiscal approach[9] and the anterior approach[10], as well as other imaging guides such as computerized axial tomography (CT) and ultrasound (US)[11],[12].

The present study aimed to perform a systematic review of the literature to evaluate the effectiveness of SHPB in adult patients with pelvic-abdominal cancer pain in terms of pain control, opioid dose and the quality of life of the patients.

\section{Methodology}

Literature review strategy An electronic review of the literature was carried out in PubMed, EMBASE and Scopus, combining the following MeSH terms and key words: "Hypogastric Plexus [Mesh]", "Nerve Block [Mesh]", "cancer pain" [Mesh]", superior hypogastric plexus neurolytic block (SHPB) [Mesh]", Pelvic cancer pain (Mesh]", Ultrasonography [Mesh]", Phenol [Mesh]", gynecological cancer [Mesh]". The search was limited to January 1, 1990, to August 31, 2019, without a language restriction. A manual search was also carried out in the references of the articles reviewed.

Inclusion criteria Clinical descriptive and/or analytical longitudinal studies (retrospective or prospective) and controlled clinical trials that evaluated the following were included in adult patients diagnosed with pelvic-abdominal cancer with secondary oncological pain with treatment SHPB (using the classic or fluoroscopy-guided transdiscal technique) Pediatric studies ( $<16$ years of age), experimental studies in animals, studies in cadavers, reports of cases with less than 10 patients and studies that only describe blocking techniques were not included.

Selection of studies and quality evaluation Two authors (PD, HC) independently assessed the titles and abstracts identified in the literature review and selected studies that met the inclusion criteria. Data related to the study design, demographic variables, type of intervention technique and clinical results reported were extracted.

The Jadad and Ottawa-Newcastle scales were used to evaluate the quality of the randomized clinical trials and the longitudinal descriptive studies, respectively[13],[14].

A third reviewer (PR) contributed to resolve any disagreement during the development of this phase. Statistical analysis Given the heterogeneity and low quality of the studies reviewed, only the systematic review of the literature was carried out. The evaluated variables were grouped; qualitative variables were described using frequencies, and quantitative variables were described using the statistical mean. The statistical package SPSS 24 was used. Research approved by the institutional ethics committee.

\section{Results}

In total, 287 bibliographical references were found: 26 in PubMed; 42 in EMBASE; 210 in Scopus; and one from other sources. Seventy-four were discarded due to duplicity. Eighteen were chosen for complete review. Three of them did not provide the full text. Finally, eight met the inclusion criteria of the 


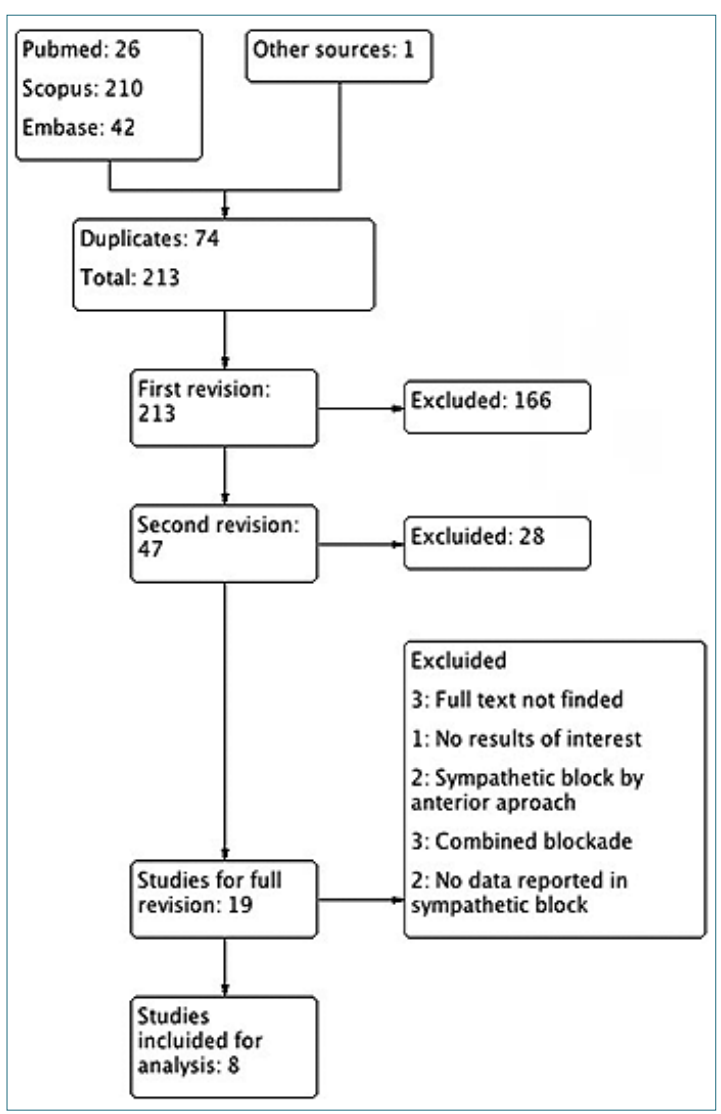

Figure 1. Study flow diagram - PRISMA.

study (Figure 1).

Characteristics of the studies Six studies were descriptive, longitudinal studies[8],[15]-[19] with a follow-up period between 2 months and 3 years, and two were controlled clinical trials. Gamal et al.[9], compared two hypogastric plexus approach techniques (transdiscal and classic), which independently provided the patient data for each group; Ghoneim et al.[20], compared the anterior approach versus the classic posterior approach using CT, from which only the data from the second group of patients were considered for being a source of interest for the present work.

The entire studies compared the results of the patients regarding their characteristics prior to the blockade. None of the works compared SHPB versus medical management.

The total number of patients was 316; 75\% female and $25 \%$ male. The average age was 53.2 years. The most frequent diagnoses were cancer of gynecological (68\%), genitourinary tract (18.6\%) and colorectal $(10.7 \%)$ origin. The classic paramedian and neurolytic approach was used in most of the cases. In all cases, phenol $10 \%$ was used. Most of the studies[8],[9],[15]-[17],[19],[20] evaluated the effectiveness of the technique based on the reduction in pain intensity in terms of the VAS and on the reduction in the dose of opioid analgesics (MME) per day.

Only three studies[(7],[19],[20] evaluated the patients' post-block quality of life, using the European Organization for Research and Treatment of Cancer (EORTC) Quality of Life questionnaire (QLQ-C30), Patient Satisfaction Scale (PSS) and Zubrod scale, respectively (Table 1). https://revistachilenadeanestesia.cl/PI// table-1-revchilanestv49n06-07.pdf

Quality of the studies None of the evaluated studies obtained high quality scores (namely, a Jadad score $\geq 3$ or an Ottawa-Newcastle score $>9$ ) (Table 2).

Clinical outcomes Visual Analog Scale Pain intensity was evaluated using the VAS. Plancarte et al. 1990[8] reported a 70\% reduction on the VAS. De León-Casasola et al. 1993[18] and Plancarte et al. 1997[15], reported a VAS value of 10 before the block, reducing it to less than 4 after the block in $69 \%$ and $72 \%$ of the patients, respectively. In the other studies, patients were evaluated using the VAS before the block, and then reassessed periodically from the first day and, in some patients, up to 6 months after the neurolytic block. The mean VAS value before the block was $7.81 \pm 1.3$; after 24 hours, the mean was $3.06 \pm 0.86$, and after one month, it was $3.53 \pm$ 0.63 . The average reduction in pain ranged between $55 \%$ and $60.8 \%$ during the first month postneurolytic block (Figure 2).

Successful block a 50\% reduction of the MME per day and/or reduction in the pain intensity to a VAS value $<4$ was considered a successful block. In general, in $78 \%$ of the cases the blockade was successful, and the effect remained over time. De León-Casasola et al. 1993[18] and Plancarte et al. 1997[15] reported the highest frequency of failed neurolytic blocks (31\% and $28 \%$, respectively), which were attributed to the tumor invasion in the retroperitoneal space (confirmed by CT), preventing the adequate distribution of the neurolytic agent (Table 1).

Morphine milligram equivalents (MME) per day. On the other hand, opioid consumption was significantly reduced after the blockade. Two studies (Plancarte et al. 1993[8] and Agüero et al. 1999[19] did not report MME per day before or after the blockade. In the other studies, baseline MME per day varied significantly from one study to another, with doses as high as 953 mg/day and doses as low as 26.8 mg/ 
day, which suggests that some blockades were performed at different points of the analgesic ladder; namely, some blockades were performed earlier than others, probably as rescue therapies. Erdine et al. 2003[16], recruited patients with analgesic management in the second step of treatment who were being treated with weak opioids like codeine with much lower MME than those of De León-Casasola et al. 1993[18], who included patients with advanced pathology and severe pain despite high doses of opioids and/or with undesirable side effects such as sedation and in whom the SHPB was part of the fourth step of the analgesic ladder.

In general, after the blockade, a significant reduction in opioid requirements was achieved-between $40 \%$ and $62 \%$ of the basal dose-which remained over time (Figure 3).

Quality of life and patient satisfaction Three studies evaluated the quality of life of the patients. Nabil et al., 2010[17], used the QLQ-C30, whose score decreased significantly $(p<0.05)$ from $74 \pm 10$ to $53 \pm$ 9 one week after the blockade and remained without significant changes during follow-up. On the other hand, Ghoneim et al. 2014[20] evaluated quality of life through the PSS, which is a linear analog scale ranging from 0 to 10 , where 0 indicates very dissatisfied and 10 indicates very satisfied, and the estimation was determined by the patient. The mean PSS score increased significantly $(p<0.05)$, from $3.4 \pm$ 0.8 to $4.13 \pm 0.72$ the first day after the blockade and did not change during the two months of follow-up. Agüero et al. 1999[19] used the Zubrod scale, which ranges from 0 to 5, where 0 is the asymptomatic patient, able to walk and have normal activity, and 5 is the patient who has died. The pre-blockade value was 3.38, which corresponds to a severely disabled patient who spends more than $50 \%$ of the time in bed but is able to stand up. This value decreased significantly in the first 24 hours (2.25) and remained stable until the third month, when it began to return to its baseline value (Table 1).

Complications and adverse events The presence of adverse events and minor complications is relatively frequent, occurring in $18 \%$ (58) of all cases, mostly of low complexity and mainly related to pain caused by the insertion of the needle, followed by vascular puncture, although the presence of retroperitoneal hematomas and/or the intravascular administration of the neurolytic block was not reported. The puncture of the ureters was also described, but without associated complications, and finally, diarrhea occurred after the blockade, which was self-limiting in all cases (Table1).

\section{Discussion}

Patients with pelvic-abdominal tumor extension usually experience severe pain that does not respond to opioid analgesics, requiring increasing their doses progressively, but with side effects such as excessive sedation which limits the acceptability and usefulness of these analgesics. Therefore, an invasive approach is necessary to control pain and improve the quality of life of these patients.

The effectiveness of the blockade was originally demonstrated by Plancarte et al. 1990[8], when a neurolytic agent was administered to a group of 28 patients with pelvic-abdominal pain of oncological origin, achieving a decrease in the VAS to $30 \%$ of the baseline level. In a subsequent study, De Leon-Casasola et al. 1993[18] showed a successful blockade in $69 \%$ of the cases, associated with a reduction in the daily dose of opioids (MME) between $45 \%$ and $67 \%$. Similar findings were also described by Plancarte et al. 1990[15] in a study that reported the largest number of patients until now, where out of 159 patients, $72 \%$ presented satisfactory pain relief, with a $40 \%$ reduction in the baseline MME per day level. In these last two studies, it is striking that there were a significant number of failed blocks (28\%-31\%), which is explained by their late use (as rescue therapies), when tumor invasion at the retroperitoneal level is important, obstructing adequate distribution of the neurolytic agent at this level. This complication can be corrected with a second blockade by increasing the neurolytic dose. A clinical trial recently published by Amr et al. 2014[5], compared an early sympathetic blockade (before the second step of the analgesic ladder) versus a late blockade (as part of the fourth step) in 109 patients with oncological pain secondary to abdominal and/or pelvic cancer. The outcome showed a greater effectiveness of the early blockade in managing pain due to a significant reduction in the VAS and MME in the first 12 months of follow-up as well as a significant improvement in quality of life during the first 5 months of follow-up. These results support the argument that an early block would show a higher success rate than that found in the studies published to date.

The decrease in the post-block VAS value may also be related to the approach used. Gamal et al. 2006[9], compared two SHP approach techniques: the fluoroscopy-guided transdiscal approach versus the classic approach. Thirty patients with oncological pain were randomly assigned to one of the two groups, and the VAS and MME dose were evaluated in regard to baseline and between groups. The out- 


\begin{tabular}{|c|c|c|c|c|c|}
\hline Study & $\begin{array}{l}\text { Scale Ottawa } \\
\text { o Jadad }\end{array}$ & Study type & No. patients & Results & $\begin{array}{l}\text { Follow-up } \\
\text { period }\end{array}$ \\
\hline Plancarte et al. 1990 & 7 & Longitudinal & 28 & $\begin{array}{l}\text { VAS, successful block, compli- } \\
\text { cations }\end{array}$ & 2 years \\
\hline Casasola et al. 1993 & 7 & Longitudinal & 26 & $\begin{array}{l}\text { (MME) per day, successful } \\
\text { block, complications }\end{array}$ & 6 months \\
\hline Plancarte et al. 1997 & 7 & Longitudinal & 159 & $\begin{array}{l}\text { (MME) per day, successful } \\
\text { block, complications }\end{array}$ & 3 years \\
\hline Agüero et al. 1999 & 7 & Longitudinal & 16 & VAS, quality of life & 6 months \\
\hline Erdine et al. 2003 & 7 & Longitudinal & 20 & $\begin{array}{l}\text { VAS, (MME) per day, suc- } \\
\text { cessful block, complications }\end{array}$ & 3 months \\
\hline Nabil et al. 2010 & 8 & Longitudinal & 22 & $\begin{array}{l}\text { VAS, (MME) per day, suc- } \\
\text { cessful block, Quality of life, } \\
\text { complications }\end{array}$ & 2 months \\
\hline Gamal et al. 2006 & 2 & RTC & 30 & $\begin{array}{l}\text { VAS, (MME) per day, suc- } \\
\text { cessful block, complications }\end{array}$ & 3 months \\
\hline Ghoneim et al. 2014 & 2 & RTC & 15 & $\begin{array}{l}\text { VAS, (MME) per day, suc- } \\
\text { cessful block, Quality of life, } \\
\text { complications }\end{array}$ & 2 months \\
\hline
\end{tabular}

Source: Authors.

'The Jadad scale was used to evaluate the quality of randomized clinical trials (Gamal et al. 2006 and Ghoneim et al. 2014) and Ottawa-Newcastle scale was used to evaluate longitudinal descriptive studies.

VAS: Visual Analog Scale; MME: Morphine Milligram Equivalents per day.

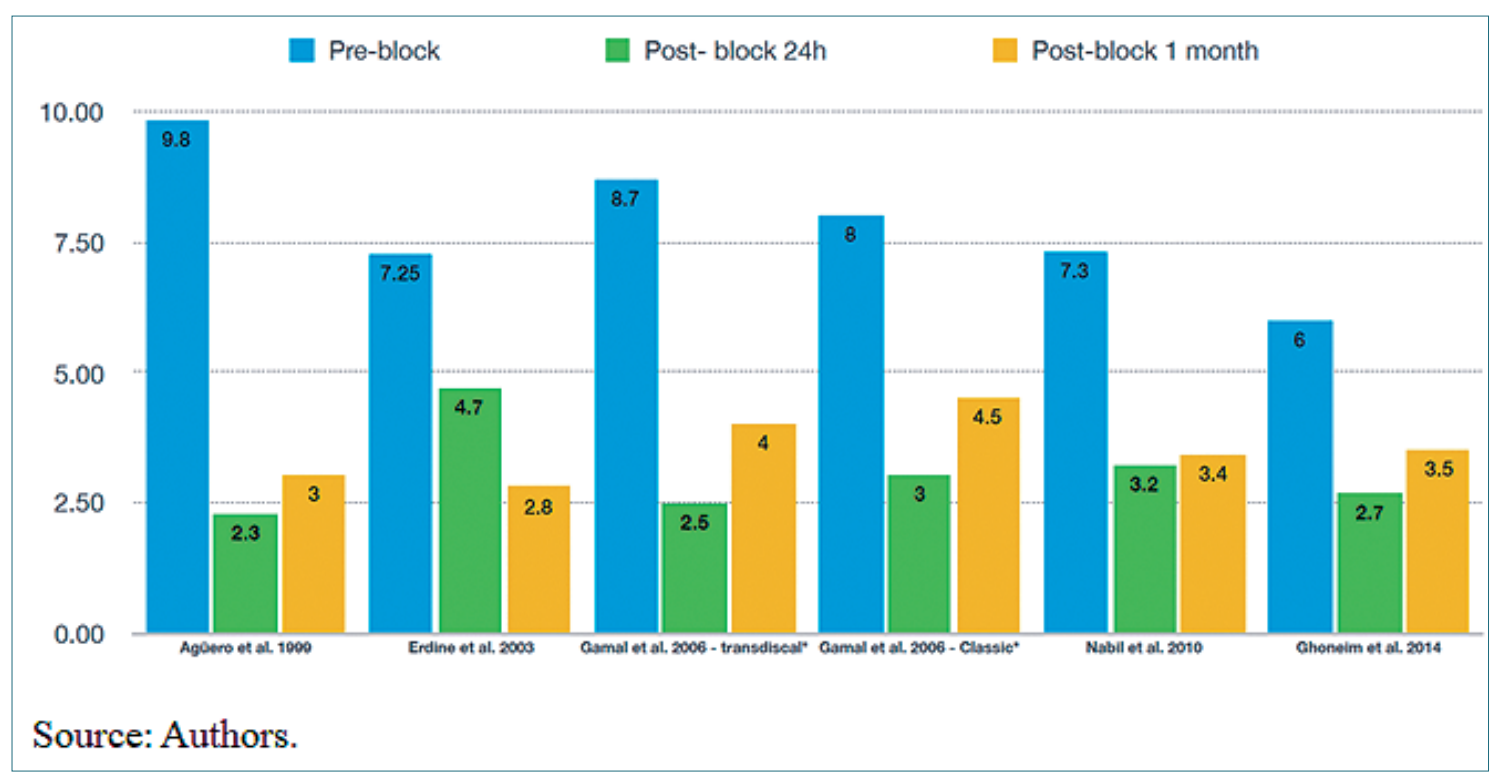

Figure 2. Evaluation Visual Analogue Scale. 


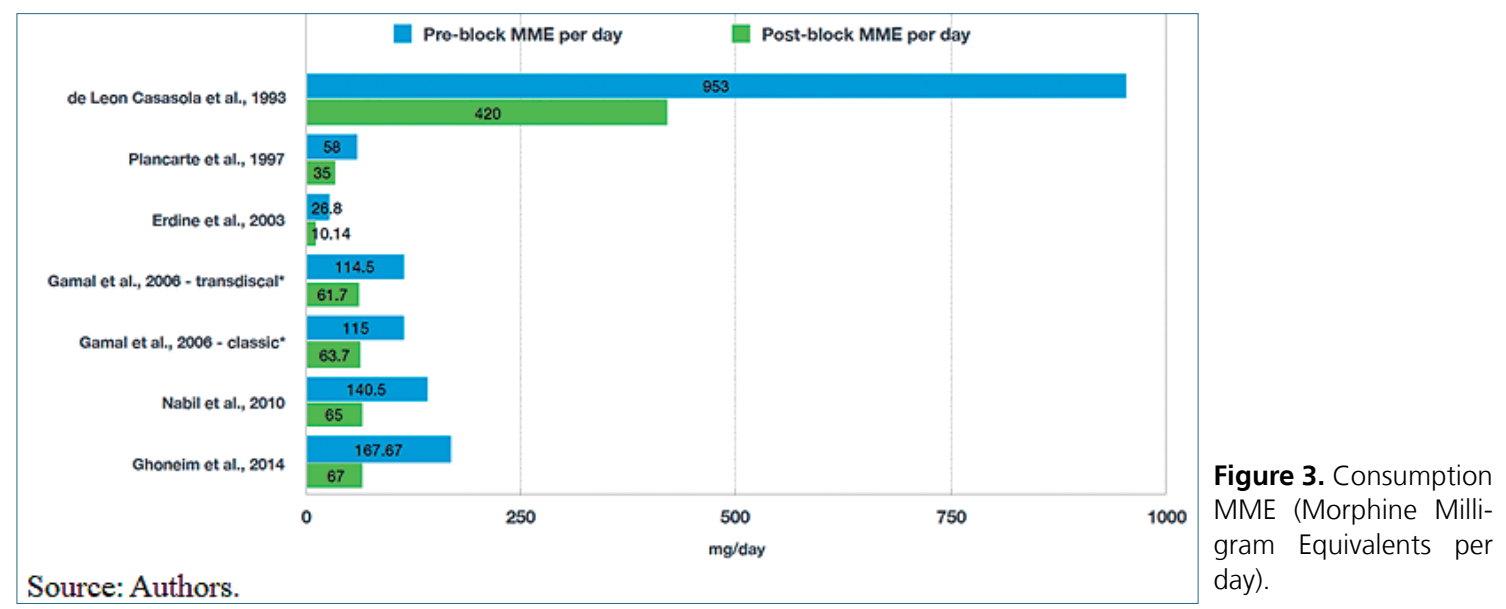

come showed a successful blockade in $100 \%$ of the cases with a transdiscal approach, unlike an $86 \%$ success rate with the classic technique. The decrease in pain on the VAS and the opioid dose (MME) showed no significant differences between the groups. However, the classic approach showed more complications (puncture of the ureter in 4 cases and vascular puncture in 2 cases), and the procedure time was longer (57.9 minutes versus 25.4 minutes). These findings suggest that the transdiscal approach is easier and safer to perform and is probably more effective and has a lower incidence of complications and adverse events. However, additional studies are required to verify these findings.

On the other hand, different imaging approaches and guides have been described, also with positive clinical results. Ghoneim et al. 2014[20], compared the CT-guided anterior approach versus the fluoroscopy-guided classic approach. Only the data of the latter approach was considered, reporting a successful block in $80 \%$ of the cases. However, in the group with the anterior approach, the success rate was $100 \%$. There was a significant difference in the VAS and in MME compared to baseline, but not between the groups. No complications were reported with the anterior approach, and patients reported a greater satisfaction with this procedure. These findings suggest that this new technique could be more effective and safe[20].

There are different SHP approach neurolytic techniques, all with similar success rates. Currently, strategies that provide greater safety and efficacy are being studied; thus, some researchers consider that using ultrasound as a guide is an excellent option given the advantages it provides, such as the non-irradiation of the patient and the interventionist, the possibility to observe in real time the different structures (especially the vascular ones) and the distribution of the neurolytic agent[12],[21]-[23] that evaluated the quality of life and satisfaction of post-block patients[17],[19],[20], reported a significant improvement in the scales used relative to baseline values. These findings can be explained by adequate pain management, which decreases the risk of depression and improves the ability to walk, reducing complications associated with the use of high doses of analgesics and leading to a greater adherence to palliative treatment.

\section{Conclusions}

The neurolytic block of the SHP (classic approach and/or fluoroscopy-guided transdiscal approach) may be an effective and safe strategy for the control of pain secondary to pelvic-abdominal cancer, achieving a significant reduction in the severity thereof (evaluated by the VAS). The reduction in MME per day reflects a high success rate, which can be improved if performed early. Failed blockades have been associated with a more advanced stage of the disease and a greater likelihood of invasion into the retroperitoneal space. In general, the patients presented a significant improvement in the quality of life and the level of satisfaction after the block.

Despite the low quality of the studies, this technique demonstrated its utility as a coadjuvant in the management of severe oncological pelvic-abdominal pain.

Acknowledgments: Assistance for the study: none 
Bloqueo del plexo hipogástrico - D. P. Pérez-Moreno et al.

Funding source: The authors declare that no funding was received from any governmental or private entity. Conflict of interest: The authors declare that they have no conflicts of interest to disclose.
Anexo 1: https://revistachilenadeanestesia.cl/PII/Anex1-revchilanestv49n06-07.pdf

Presentations: none.

\section{References}

1. Miguel R. Interventional treatment of cancer pain: the fourth step in the World Health Organization analgesic ladder? Cancer Contr. 2000 Mar-Apr;7(2):149-56. https:// doi.1177/107327480000700205 PMID:10783819

2. Carlson CL. Effectiveness of the World Health Organization cancer pain relief guidelines: an integrative review. J Pain Res. 2016 Jul;9(9):515-34. https:// doi.org/10.2147/JPR.S97759 PMID:27524918

3. Sindt JE, Brogan SE. Interventional Treatments of Cancer Pain. Anesthesiol Clin. 2016 Jun;34(2):317-39. https://doi.org/10.1016/j. anclin.2016.01.004 PMID:27208713

4. de Oliveira R, dos Reis MP, Prado WA. The effects of early or late neurolytic sympathetic plexus block on the management of abdominal or pelvic cancer pain. Pain. 2004 Jul;110(1-2):400-8. https://doi. org/10.1016/j.pain.2004.04.023 PMID:15275792

5. Amr YM, Makharita MY. Neurolytic sympathectomy in the management of cancer pain-time effect: a prospective, randomized multicenter study. J Pain Symptom Manage. 2014 Nov;48(5):944-56. e2. https://doi.org/10.1016/j. jpainsymman.2014.01.015 PMID:24798104

6. Rigor BM Sr. Pelvic cancer pain. J Surg Oncol. 2000
Dec;75(4):280-300. https:// doi.org/10.1002/10969098(200012)75:43.0.CO;2-Q PMID:11135274

7. Plancarte R. Dolor abdomino pelvico y su tratamiento. Rev Mex Anest. 2002;25(42):289-97.

8. Plancarte $R$, Amescua C, Patt RB, Aldrete JA. Superior hypogastric plexus block for pelvic cancer pain. Anesthesiology. 1990;73(2):236-9. http://www.ncbi.nlm.nih.gov/ pubmed/2382849 https:// doi.org/10.1097/00000542199008000-00008.

9. Gamal G, Helaly M, Labib YM. Superior hypogastric block: transdiscal versus classic posterior approach in pelvic cancer pain. Clin J Pain. 2006;22(6):544-7. Available DOI: http://www.ncbi.nlm.nih.gov/ pubmed/16788341

10. Kanazi G, Perkins F, Thakur R, Dotson E. New technique for superior hypogastric plexus block. Regional Anesthesia and Pain Medicine. BMJ; 1999 Sep;24(5):473-6. http://dx.doi.org/10.1016/s10987339(99)90018-4

11. Michalek P, Dutka J. Computed tomography-guided anterior approach to the superior hypogastric plexus for noncancer pelvic pain: A report of two cases. Clin J Pain. 2005;21(6). https://doi.org/10.1097/01. ajp.0000146214.08910.21.

12. Mishra S, Bhatnagar S, Rana SP, Khurana D, Thulkar S. Efficacy of the Anterior Ultrasound-Guided Superior Hypogastric Plexus Neurolysis in Pelvic Cancer Pain in Advanced Gynecological Can- cer Patients. Pain Med [Internet]. 2013 Jun;14(6):837-42. academic.oup.com/painmedicine/articlelookup/doi/10.1111/pme.12106 https://doi.org/10.1111/ pme. 12106.

13. Jadad AR, Moore RA, Carroll D, Jenkinson C, Reynolds DJM, Gavaghan DJ, et al. Assessing the quality of reports of randomized clinical trials: is blinding necessary? Control Clin Trials. 1996;(1):1-12. https://doi.org/10.1016/01972456(95)00134-4.

14. Stang A. Critical evaluation of the Newcastle-Ottawa scale for the assessment of the quality of nonrandomized studies in metaanalyses. Eur J Epidemiol. 2010 Sep;25(9):603-5. https://doi. org/10.1007/s10654-010-9491-z PMID:20652370

15. Plancarte $R$, de Leon-Casasola OA, El-Helaly M, Allende S, Lema MJ. Neurolytic superior hypogastric plexus block for chronic pelvic pain associated with cancer. Reg Anesth. 1997 Nov-Dec;22(6):562-8. PMID: 9425974.

16. Erdine S, Yucel A, Celik M, TaluGK. Transdiscal approach for hypogastric plexus block. Reg Anesth Pain Med. 2003;28(4):304-8. https://pubmed.ncbi.nlm.nih. gov/9425974/

17. Nabil D, Eissa AA. Evaluation of posteromedial transdiscal superior hypogastric block after failure of the classic approach. Clin J Pain. 2010 Oct;26(8):6947. https://doi.org/10.1097/ AJP.0b013e3181dedfa9 PMID:20664339 
18. de Leon-Casasola OA, Kent E, Lema MJ. Neurolytic superior hypogastric plexus block for chronic pelvic pain associated with cancer. Pain. 1993 Aug;54(2):145-51. https:// doi.org/10.1016/03043959(93)90202-Z PMID:8233527

19. Martínez MA, Jorge LY. Tratamiento del dolor pélvico visceral de origen neoplásico con neurólisis del plexo hipogástrico superior. Rev Cuba Oncol. 1999;15(3):176-81. https://doi.org/10.1016/03043959(93)90202-Z.

20. Ghoneim AA, Mansour SM. Comparative study between computed tomography guided superior hypogastric plexus block and the classic posterior approach: A prospective randomized study. Saudi J Anaesth. 2014;8(3):378-83. www.saudija.org/article.asp? issn $=1658354 \mathrm{X}$; year $=2014$; $\mathrm{v}$ olume $=8$; issue $=3 ;$ spage $=378$ ;epage=383; aulast=Ghoneim https://doi.org/10.4103/1658354X.136625.

21. Gofeld M, Lee CW. UltrasoundGuided Superior Hypogastric Plexus Block: A Cadaveric Feasibility Study with Fluoroscopic Confirmation. Pain Pract. 2017 Feb;17(2):192-6. https:// doi.org/10.1111/papr.12437 PMID:26945508
22. Baig S, Moon JY, Shankar H. Review of sympathetic blocks: Anatomy, sonoanatomy, evidence, and techniques. Reg Anesth Pain Med. 2017 May/Jun;42(3):37791. https://doi.org/10.1097/ AAP.0000000000000591 PMID:28272291

23. Bhatnagar S, Khanna S, Roshni S, Goyal GN, Mishra S, Rana SP, et al. Early ultrasound-guided neurolysis for pain management in gastrointestinal and pelvic malignancies: an observational study in a tertiary care center of urban India. Pain Pract. 2012 Jan;12(1):2332. https://doi.org/10.1111/ j.1533-2500.2011.00467.x PMID:21615855 